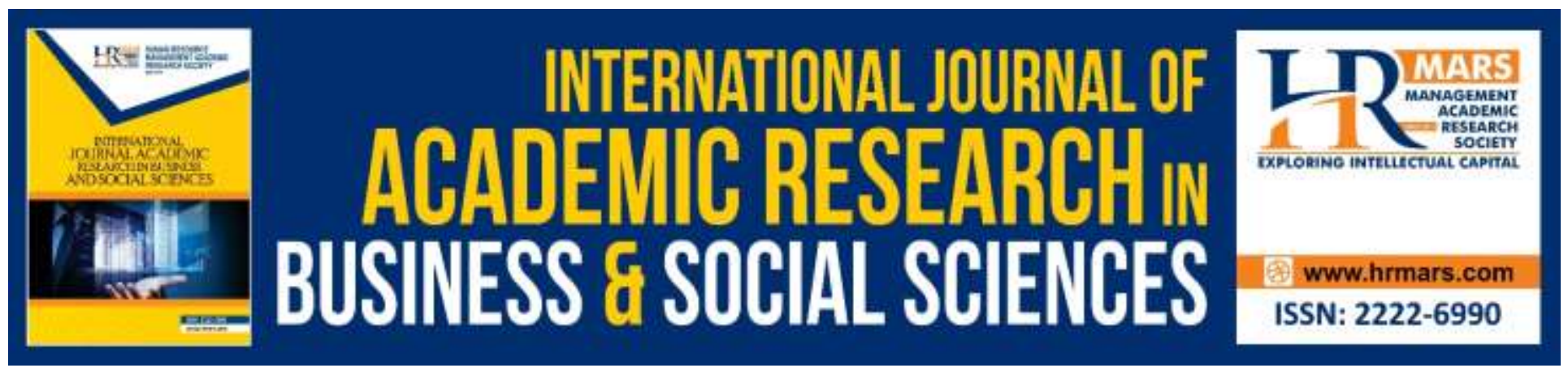

\title{
Products Packaging and Its Effects on Consumer Patronage of Cadbury Plc Nigeria
}

Femi Seun Benjamin, Temitope Ajisafe, Amamhe Christerbel Adare, Olaiya Hammed Ayodele

To Link this Article: http://dx.doi.org/10.6007/IJARBSS/v9-i7/6150

DOI: $10.6007 /$ IJARBSS/v9-i7/6150

Received: 12 May 2019, Revised: 01 June 2019, Accepted: 23 June 2019

Published Online: 13 July 2019

In-Text Citation: (Benjamin, Ajisafe, Adare, \& Ayodele, 2019)

To Cite this Article: Benjamin, F. S., Ajisafe, T., Adare, A. C., \& Ayodele, O. H. (2019). Products Packaging and Its Effects on Consumer Patronage of Cadbury Plc Nigeria. International Journal of Academic Research in Business and Social Sciences, 9(7), 590-613.

Copyright: (C) 2019 The Author(s)

Published by Human Resource Management Academic Research Society (www.hrmars.com)

This article is published under the Creative Commons Attribution (CC BY 4.0) license. Anyone may reproduce, distribute, translate and create derivative works of this article (for both commercial and non-commercial purposes), subject to full attribution to the original publication and authors. The full terms of this license may be seen

at: http://creativecommons.org/licences/by/4.0/legalcode

Vol. 9, No. 7, 2019, Pg. 590 - 613

http://hrmars.com/index.php/pages/detail/IJARBSS

JOURNAL HOMEPAGE

Full Terms \& Conditions of access and use can be found at http://hrmars.com/index.php/pages/detail/publication-ethics 


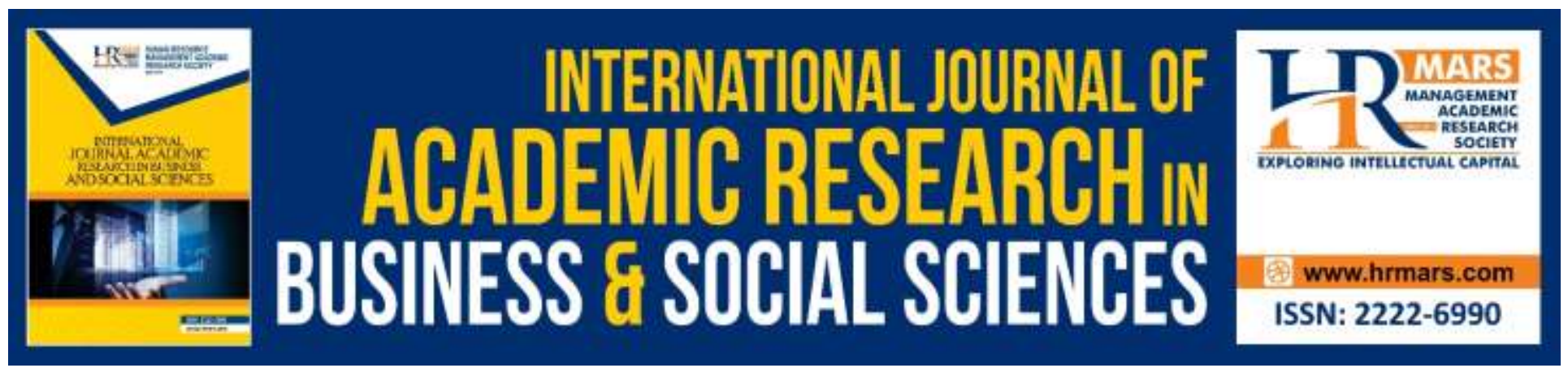

\title{
Products Packaging and Its Effects on Consumer Patronage of Cadbury Plc Nigeria
}

\section{Femi Seun Benjamin, Temitope Ajisafe, Amamhe Christerbel Adare, Olaiya Hammed Ayodele}

Department of Business Administration, Adekunle Ajasin University, Akungba-Akoko, Nigeria Email: bendistributor@gmail.com

\begin{abstract}
The study appraised the effect of product packaging on consumer patronage of Cadbury Plc Nigeria; and examined the effect of product packaging on market share of Cadbury product in Nigerian. Primary data were sourced for the study. The data were obtained through administration of a questionnaire to 154 respondent of Cadbury in Nigeria. simple random technique was also used in selecting management staff of the organisation. These respondents were in the positions to supply the type of information needed for this study. Data collected were analyzed using simple percentages, frequencies distribution, mean, standard deviation and median; and regression analyses. The results of the analysis revealed as indicated by the respondents that product packaging has s significant effect on consumer patronage. This is shown in response as $50 \%$ of the respondents in the survey agreed that consumer buying behavior is been influence by product packaging. This is also shown in response as $50 \%$ of the respondents in the survey Strongly agreed that product packaging influence the performance of an organization. This study further showed that product packaging has the ability to increase the sale of an organization as showed in response as 60\% of the respondents agreed that packaging has a positive relationship with sale volume of an organization. From the findings, in the Hypothesis 1, F stats of 28.772 was obtained. This was significant as the $p$ value is less than 0.05 . From the findings, Hypothesis 2, F stats of 26.865 was obtained. This was significant as the $p$ value is less than 0.05. The study concluded that Product packaging has been found to have favorable effect on consumer patronage and consumer purchasing decision as well as increasing the sales of an organization. Thus, product packaging should be seen as inevitable tools in an organization, small, medium and large scale enterprise. However, before this could be achieved, a thorough market survey should be undertaken in other to achieve the desired result. The study recommends that Management should consult with the marketing, sales and production department on the kind of packaging tools which will be effective and attractive enough and the one that is cost effective.

Keywords: Product Packaging, Consumer Patronage, Market Share, Consumer Behaviour
\end{abstract}


INTERNATIONAL JOURNAL OF ACADEMIC RESEARCH IN BUSINESS AND SOCIAL SCIENCES Vol. 9, No. 7, July, 2019, E-ISSN: 2222-6990 @ 2019 HRMARS

\section{Introduction}

In recent years, packaging has developed well beyond its original function as merely a means of product protection and now plays a key marketing role in developing shelf appeal, providing product information and establishing brand image, awareness and increasing sales. (Cateora \& Graham, 2002). Packaging today has grown in importance in the face of stiff competition clamouring for the consumer's attention. This is buttressed by Underwood, Klein and Burke (2001) who said packaging is also utilized as a marketing tool to get the consumer's attention, to promote and convey messages about the products attributes to consumers whilst still on the shelf or at the point of sales.

Packaging is considered as the fifth ' $p$ ' of marketing after product, price, promotion and place (Schrawet and Kundu, 2007 in Nayyar, 2012; Ladipo and Rahim, 2013) and as the fifth ' $p$ ' of marketing, Kotler (2000) cited in Nayyar (2012) defined packaging as the activities of designing and producing the container or wrapper for a product. This means that companies must monitor and change product packaging on a regular basis to ensure its continuous and increasing appeal to target audiences (Ladipo and Rahim, 2013; Oladele, 2012). packaging has developed into one of the most sophisticated, holistic and influential examples for those who design it and for those people who are considered intermediates for selling products from manufacturers to the end consumers (Nayyar, 2012). Packaging of a product is therefore, an important issue in the growing use of packaging as a marketing tool for self-service, since $73 \%$ of products are sold on a self-service bases at the point of sale (Silayoi and Speece, 2004). Packaging plays a major role when products are purchased; after all, it is the first thing seen before making purchase choices (Kamaladevi, 2010; Galdeano, Ahmed, Fati, Rehan, \& Ahmed, (2019).

There is huge competition in the business world, both locally and globally, and businesses are competing with other businesses for consumers. Organizations now engage in good packaging and repackaging of their product making it difficult for consumers to make choices among different competing product. This business world is changing also. As trends change, the desires of the consumers are changing as well. Product packaging in general is intended to protect the product but as at now, it is also intended to increase sales. According to Ladipo and Rahim, (2013) package attracts consumer's attention to particular brands, enhances its image, and influences consumer's perceptions about products, thus packaging a certain product based on your consumer needs, the producer can use labeling or image description to arouse the interest of the consumer to purchase that product, when the consumer is moved by the image or label used to package the product he or she desires or makes a purchase for that product that is needed.

A lot of firms in the industry have embarked on one strategy or the other in order to gain more market share for their products. In an attempt to get more customers to purchase their products, companies have engaged in different innovations so as to make their product compete with that of competitors, the packaging form is one way to gain consumer notice (Oladele, 2012). Best (2002), opined that attractive packaging creates value by helping consumer decision process, which mean that Attractive packaging calls for repeated patronage from consumers, which enable the firm to generate profit. Scot (2008) stated that attractive packaging can attract customers to try product at first sight. As packaging's role in the marketing mix gains momentum, so research into this arena becomes increasingly important hence this study. 


\section{Statement of the Problem}

Now, packaging has become itself a sales promotion tool for the organizations. The consumer's patronage also is stimulated by the packaging quality, color, wrapper, and other characteristics of packaging. Packaging is a whole package that becomes an ultimate selling proposition, which stimulates impulse buying behavior. Packaging increases sales and market share and reduces market and promotional costs. According to Rundh (2005) package appeals consumer's attentiveness towards a certain brand, increases its image, and stimulates consumer's perceptions about product. Furthermore, packaging conveys distinctive value to products (Underwood, 2003; Silayoi, \& Speece, 2007), packaging works as an instrument for differentiation, and helps consumers to decide the product from wide range of parallel products, packaging also stimulates customer's buying behavior (Wells, Farley \& Armstrong, 2007).

Previous researches show that there is no agreement on overall classification of packaging material and package elements. There is also disagreement regarding the methods of packaging impact on consumer's patronage. In order to increase sales and improve competitive advantage, these companies have been using various products packaging mix (Oladele, 2012). However, factors have been identified in literature to contribute to the frequent review of products packaging so as to be in tune with the changing society (Rundh, 2005). However, each packaging tools has advantages and disadvantages, it is therefore expedient for every organization to continue to review their packaging techniques ((Schrawet and Kundu, 2007 in Nayyar, 2012). This is necessary because factors that been identified in the literature to influence products packaging chosen by a firm in other countries. Therefore, there is needs to continuously investigate the factors that influence product packaging in Nigeria.

\section{Research Question}

What is the influence of product packaging on customer buying decisions and what are the effects of product packaging on market share?

\section{Objectives of the Study}

The main objective of this study is to appraise the role of product packaging and its influence on consumer's patronage, and the specific objective is to assess the effect of product packaging on the market share.

\section{Hypothesis of the Study}

i There is no significant relationship between product packaging and sales turnover of Cadbury plc.

\section{Significance of the Study}

Packaging is often the only promotional material available at the point of purchases which inform remind and also stimulate the buyers. Lack of adequate packaging is a concern for manufacturing firms including Nigeria. Specifically, the finding of this study is expected to benefit the following stakeholders; To the government, the study would provide greater insight into the relationship between packaging and patronage of firms. This may aid in formation of policies and regulation that can help improve Sales Volume, profitability and market shares in the sector and by extension 
increase job creation. Companies may benefit from the study as they could better understand the underlying product packaging activities influencing patronage of companies and they may be better placed to deal with hurdles that impede successful packaging performance. Based on these observations, this study may perhaps propose some future directors in order to make Nigeria companies competitive with world class best strategies. The study could also benefit the academic community as it may contribute to the increasing body of literature on product packaging.

\section{Literature Review}

\section{Conceptual Reviews}

Packaging has been defined by many authors in the literature and the various definitions are given in this study According to Keller (2003), packaging involves the activities of designing and producing containers or wrappers for a product. He concludes that packaging like other elements, must achieve a number of objectives from the perspective of both the firm and consumers namely, identity of brand; convey descriptive and persuasive information; facilitate product transportation and protection; assist at-home storage and aid product consumption. "To achieve the marketing objectives for the brand and satisfy the desires of consumer, the aesthetic and functional components of packaging must be chosen correctly" (Keller, 2003). According to Williams (1982), packaging is part of the product which encloses and protects. It is the final stage of production. Packaging helps consumers to choose from a wide range of similar products; and that it also stimulates customers buying behaviour (Wells et al, 2007). Product packaging is an essential aspect of projecting a firm's brand's image, which is sometimes designed to convey images of high quality, while at other times signalling affordable price (Urich, Campana and Malkewitz, 2010). In the selfservice world today, packaging has become a major communication medium from manufacturer or retailers to consumers (Williams, 1982). It communicates certain quality image to consumers.

Packaging influences consumers' perception for a particular product brand and consumers most times are attracted at first sight to the packaging style of a product (Lifu, 2012). Packaging can dissuade customers from buying the product irrespective of its quality (Lifu, 2003 in Lifu, 2012; Oladele, 2006). Good and attractive packaging in the view of Scott (2008) may add value to the product and attract a trial from customers. There are six variables that must be taken into consideration by producers and designers when creating efficient package. These are the form, size, colour, graphics, material and flavour (Wells et al, 2007). According to Rundh (2005) package appeals consumer's attentiveness towards a certain brand, increases its image, and stimulates consumer's perceptions about product.

Packaging is an important part of the branding process as it plays a role in communicating the image and identity of a company (Sajuyigbe, et. Al., 2013) "Packaging is the container for a product - encompassing the physical appearance of the container and including the design, color, shape, labeling and materials used.

In line with the definition given by Rundh (2005) who gave a comprehensive definition of packaging and after given consideration to the commonality of definitions given by the various authors, this definition was adopted for the purpose of this study. The various variables of packaging were given in the next section. 
INTERNATIONAL JOURNAL OF ACADEMIC RESEARCH IN BUSINESS AND SOCIAL SCIENCES

Vol. 9, No. 7, July, 2019, E-ISSN: 2222-6990 ¿ 2019 HRMARS

Variables of Packaging

Wells et al, (2007) identify, colour, Printed information, packaging material, image \& typography

\section{Colour}

Colors used in packaging can help draw consumer attention. Color of packaging is important because it used by companies to differentiate its product from other competitors. Therefore, colors play an important role in a potential customer's decision-making process. Companies use different colors for emphasizing a different mood, like, black is used for power, blue for trust, red for energy, green for balance or organic and fresh. Color is an essential component of packaging because consumers expect certain type of colors for particular products (Keller, 2009). Different colors also symbolize different meanings to consumers. For example, orange, yellow, purple they have different meanings according to the consumer perception and culture. According to Singh (2006) color perceptions vary across cultures and most of the religions are believed to have their sacred colors

\section{labels}

Labeling provides information regarding the product category, products ingredients, and product instructions. Consumers when making their mind whether to buy or not to buy a product they are guided not just by the taste, but also some other extrinsic factors such as, brand awareness, labeling, price and origin. According to Morris, J (1997) product labels help consumer to differentiate a product more easily. Labeling helps consumers spend less time needed while searching for products that are decided to be bought by them. Consumers under time pressure their decisions are influenced when the package comes with a distinctive appearance that contains simple and accurate information (Silayoi, and Speece, 2004). Nowadays, there are consumers that pay more attention to label information since they are more concerned with health and nutrition issues (Coulson, N.S., 2000)

\section{Packaging Material}

The material used in packaging is an important element which prevents the product from any damage or loss. It is more likely that the high quality material might attract customer more than low quality material. So, packaging material has strong impact on buying behavior. According to Smith and Taylor (2004) consumers link the packaging materials is associated by consumers with certain essential values of the product. In addition, consumer perceptions regarding certain materials could change the perceived quality of a product (Smith and Taylor, 2004).

\section{Image \& Typography}

It is not surprising when retail brands remain faithful to using bold colours and images to attract the interest of the consumers. Apart from pictograms, the use of photography helps to convey messages. If a manufacturer wants the consumers to always remember his/her products, the use of font styles, sizes and colours are elements that most likely would influence the memory of the consumers (Viktoria Alervall) 
INTERNATIONAL JOURNAL OF ACADEMIC RESEARCH IN BUSINESS AND SOCIAL SCIENCES

Vol. 9, No. 7, July, 2019, E-ISSN: 2222-6990 @ 2019 HRMARS

\section{Roles of Packaging}

According to Lee and Lye (2002) there are basically five functional roles that are performed by packaging.

\section{Protection and Preservation}

Lee and Lye (2002) assert that protection and preservation are roles of packaging. These involve protection from environmental, mechanical and chemical poisoning and also form contamination. Deliya and Parmar (2012) highlight that packaging provides physical protection of the objects from shock, vibration, compression and temperature. In the same line, Deliya and Parmar (2012) assert that if the product is safeguarded from becoming dirty or avoiding smudging customer hands through contamination then it is said to be a clean package.

\section{Market Appeal}

Lee and Lye (2002) identified market appeal as another role of packaging. This is to say that packaging helps in improving people's perception about the product. Packaging is used to get the consumer's attention, promote and convey messages about the product's attributes whilst still on the shelf

\section{Convenience}

Another role of packaging is to add convenience in distribution, handling, display, sale, opening, reclosing, use, and re-use (Deliya and Parmar, 2012). Lee and Lye (2002) describe the convenience offered by packaging namely; openability, reclosability, carrying and dispensing facilities. Packaging enables to carry out groupage where fragmented objects can be transported from one place to the other in one package, thus ensuring handling efficiency. According to Deliya and Parmar (2012) packaging reduces theft as once opened a package cannot be re-closed or gets physically damaged that is it shows signs of opening and is helpful in the prevention of theft. In this case packaging provides opportunities to include anti-theft devices.

\section{Helps in Identification}

Lee and Lye (2002)state that packaging helps in identification and provision of information to customers. Thus, a good packaging must contain valuable product information that consumer may need to know, information on how to transport, use, recycle, or dispose of the package or product is often contained as a label on the package.

\section{Empirical Evidence}

Deliya and Parmar (2012) carried out a descriptive study in Patan District of Gujarat (India) about the roles of packaging in stimulating the behaviour of the consumers, their aim was to discover the relationship between independent variable and dependent variables. Samples of 150 were chosen to represent respondents. The research revealed that packaging is the greatest factor and that consumer decision making is dependent on it. Furthermore, it was discovered that packaging, the colour, background image, and packaging material, innovation, design of wrapper, printed information and font style were taken as predictors in consumer behaviour. The study concluded that package could be treated as one of most valuable tool in today's marketing communications, 
necessitating more detail analysis of its elements and an impact of those elements on consumers buying behaviour. Deliya and Parmar envisaged that appropriate and vivid picture or packaging colour which delivers a happy feeling or an easy handle/open/dose/dispose package shape contributed to catch consumers' attention and interest. For this purpose the main packaging elements could be identified as graphic, colour, size, form. Similarly, material of packaging such as wrapper design, printed information, and innovation are all ingredients to product success in the market.

\section{Customer Patronage}

Consumer patronage is the degree to which a buying unit concentrates purchases over time to a particular product within a service category; product patronage develops through positive reinforcement and repetition of buying behavior, Oliver (1997). Successful service providers achieve higher customer patronage; unsuccessful business has to attract customers. This affects the net margin because it is much more expensive in advertising promotion and selling to win customers than to hold existing ones.

Cross et al (1988), observes that it costs six times as much to win customers as to retain existing ones. Customer Patronage provides the basis for a stable and growing market share Barker (1989), argues, for obvious reasons the patron customer is the key importance to manufacturing industry especially those patron customers who are higher spenders or provide long patronage. Oliver (1997), observes, 'improving customer satisfaction is a key to gaining customer patronage. Being a patron customer indicates that a customer will stay a patron, talk favorably about the bar and its services, pay less attention to competing bars and less sensitive to price and buy more as the bar introduces new services and upgrades existing services.

\section{Developing Consumer Patronage}

Behavioral scientists believe that customer patronage results from an initial product that is reinforced through satisfaction, leading to repeat purchase. Cognitive researchers emphasize the role of mental process in building consumer patronage. They believe that the consumers engage in extensive problem solving behavior involving services and attribute compassions, leading to strong customer preferences and repeat purchase. Marketers are interested not only on how customer patronage develops but also when it develops. Research evidence suggests that a great deal of customer patronage develops quite early in the context of family life.

\section{Declining Consumer Patronage}

Sovensen (1996), observes that many marketing managers are concerned with a growing trend towards consumer switching. Among the reasons given for the decline in the consumer patronage are consumer boredom and dissatisfaction with a service, the constant availability of new service providers and increased concern over price. Palmer (1998), also states that the decline in consumer patronage is attributed to the increased targeting of specialty niches and the increased diversity of shoppers. Developing a high consistence market share of consumer patrons is the ultimate goal of marketing strategy. Discovering how consumers learn about service providers and become attached to them assist marketers in achieving their goals 
INTERNATIONAL JOURNAL OF ACADEMIC RESEARCH IN BUSINESS AND SOCIAL SCIENCES

Vol. 9, No. 7, July, 2019, E-ISSN: 2222-6990 @ 2019 HRMARS

\section{Consumer patronage measurement}

Cross et al (1988) Customer Patronage can measure using stable and growing market share and consumer satisfaction as a determinant or variable use to measure patronage.

\section{Theoretical Review}

Some theories have been reviewed for the purpose of this study in order to establish a relationship between the dependent and the independent variables. The theories are: Theory of Reason Action and theory of trying

\section{Theory of Reason Action}

The Theory of Reasoned Action (TRA) is a model that finds its origins in the field of social psychology. This model developed by Fishbein and Ajzen (1975) defines the links between beliefs, attitudes, norms, intentions, and behaviors of individuals. According to this model, a person's behavior is determined by its behavioral intention to perform it. This intention is itself determined by the person's attitudes and his subjective norms towards the behavior. Fishbein and Ajzen (1975) define the subjective norms as "the person's perception that most people who are important to him think he should or should not perform the behavior in question (Fishbein and Ajzen (1975). This theory can be summarized by the following equation: Behavioral Intention = Attitude + Subjective norms

According to TRA, the attitude of a person towards a behavior is determined by his beliefs on the consequences of this behavior, multiplied by his evaluation of these consequences. Beliefs are defined by the person's subjective probability that performing a particular behavior will produce specific results. This model therefore suggests that external stimuli influence attitudes by modifying the structure of the person's beliefs. Moreover, behavioral intention is also determined by the subjective norms that are themselves determined by the normative beliefs of an individual and by his motivation to comply to the norms.

\section{Theory of Trying}

The Theory of Trying advocated by Bagozzi and Warsaw (1990) focuses on the assessment of trying to act. In other words, in theory, of trying "an attitude toward a reasoned action is replaced by an attitude toward trying and an intention is restricted to an intention to try" (Carsrud, 2009, pp. 155). In theory, of trying Bagozzi and Warsaw (1990) divided goals into two categories: intermediate and end-state goals. In relation to this theory, Gould (1997) has identified two main reasons of why consumers may fail to try to consume. Firstly, consumers may fail to consider the options available to them. Secondly, consumers may consciously refrain from buying for various reasons. The Theory of Trying (Bagozzi and Warshaw, 1990) provides an interesting alternate approach to the models previously considered. Rather than examining explicit behavior, the model assesses trying to act. Subjective norms, attitude toward the process or means of trying, attitudes and expectations of success and attitudes and expectations of failure are posed as the key antecedent variables to intention to try; itself the key precursor to trying. Past behavior has been found to influence consumer choice in a number studies (Bagozzi and Kimmel 1995, Leone, Perugini, 1999, Norman and Conner 1996), and is thus integrated as a key influence within the theory. Bagozzi (2002) suggest in discussion of this theory that rather than consumers having behavioral intentions, they rather have 
behavioral goals in many situations, and they must expend effort and make the purposive endeavor to fulfill these goals. To date the theory of trying has mostly been applied to health related decisions, and only a few studies have applied it to retail consumption decisions. Some parts of the theory have been supported empirically, but not all of the variables have been found to be significant in every test (Bay and Daniel, 2003; Ahmed, Majid, Zin, Phulpoto, W., \& Umrani, (2016). In a fillip to the theory, Gould (1997) published research into the reasons for consumers 'failing to try to consume'. In this case, consumers are said to either fail to see or be ignorant of their options, or make a conscious effort not to consume.

\section{Empirical Review}

Sharma (2008) focused on existing practice of branding, packaging and labeling of new products in consumer-product manufacturing units. The study method was a descriptive presentation of facts collected through questionnaire surveys concerned with different sections of consumer new products and the study further investigated the new consumer-product packaging and labeling status in manufacturing units. The study concluded that consumers are aware of the value of packaging and labeling. The majority of the consumer products (84.37\%) use product labels as a simple tag attached to the product or an elaborately designed graphic that is part of the package.

Wright (2010) asserted that the food and drink industry accounts for more than half of the world's packaging market, ahead of sectors such as cosmetics, pharmaceuticals and healthcare/medicine. The share of the packaging market taken by food and drink is particularly high in the glass sector, owing to the dominance of glass bottles in the beverages industry (Wright, 2010). However, food and drink applications account for more than half of apparent consumption for all types of packaging material except metal (which has a share of fewer than 50\%) (Wright, 2010). By 2014, the plastics sector is expected to become the market's largest share, driven by continuing technological innovations such as improvements in barrier protection. This trend is expected to increase the penetration of flexible forms of plastic packaging such as pouches within the food industry. In contrast, demand for paper, glass and metal packaging is likely to remain at more static levels, although all three materials are expected to retain a significant presence in the food and drink industry (Wright, 2010)

Patrick, Bisi, Chibogu, Ebenezer (2015) examined the effect of packaging on the patronage of toothpaste among consumers in Ado-Ekiti metropolis, Nigeria. A total of 320 questionnaires were administered to respondents who were customers to eight most popular supermarkets through purposive sampling technique. Pearson-moment correlation analysis was used to determine the relationship between packaging information and patronage of toothpaste. Multiple regression was used to determine the influence of packaging attributes on patronage of toothpaste. The result revealed that among packaging information available on toothpaste products, expiry date, NAFDAC number and nutritional composition had the strongest relationship with patronage. The packaging attributes with highest influence were quantity, quality, and colour. The study recommended that manufacturers should place on their products only relevant information that will influence purchase decision. Furthermore, as families are growing, companies should be innovative to produce family size toothpaste tubes that will be cost saving for the consumers. 
Adeola (2017) determined the effect of product packaging on Nigerian consumers. The knowledge derived from relevant literature was used to draft out organized questionnaires to be filled by respondents residing in Yola and Jimeta towns, Adamawa State, Nigeria. A total of 270 questionnaires were distributed to respondents but only 222 questionnaires turned out valid. With the information gathered, it underwent analysis with the help of SPSS 21.0 and Microsoft Excel software. On the SPSS package, correlation and significance (2 tailed) were used as statistical tools. Recommendations are that marketers should know and understand the importance of product packaging because of its benefits as Nigerian consumers consider the packaging of products at the time of purchase.

Chukwu and Enudu (2018) investigated the impact of product packaging on consumer buying behavior. Poor packaging can dissuade consumers from buying product. In addition, a poorly packaged product poses serious problem to salesmen, since it will require enough explanations to persuade customers to buy the product. Customers dislike shabbily packaged products. Good and attractive product packaging influence consumers buying behavior by making them to buy product and always patronize product. A survey was used for this purpose. The data collected from the questionnaire instrument were analyzed using percentages and Multiple Regression. The research findings show that a significant and positive relationship lies between the independent variable, attractive packaging, value and quality of packaging, impulse purchasing and the dependent variable consumer buying behavior. A negative relationship exists between the independent variable shabby packaging and the dependent variable consumer purchasing behavior. We conclude that attractive packaging influences consumers purchasing behaviour, adds value and quality to product, appeal to customers and also induces impulse purchasing. We recommend that to be able to be sustainable in present day competitive and computerized market, firms should be able to balance both packaging and quality to meet the level of cost they need as well as build customers confidence, loyalty and continuous patronage

Lifu (2012) in his research on the effects of packaging on buying choice, showed that majority of respondents used in the study believed that the choice of buying a product is determined by the product packaging. He argued that the perceptions of respondents towards the value added to packaging vary as majority of the consumers believe that good and attractive packaging adds values and quality to the product.

\section{Conceptual Framework}

The relationship between independent and dependent variables was showed in this framework. packaging acts as the independent variable and it will be measured using: colour,and label. The patronage will be act as the dependent variable and it will be measured using: market share.

The moderating variable was size of the firm and top management support. This is diagrammatically show in fig 2.1 


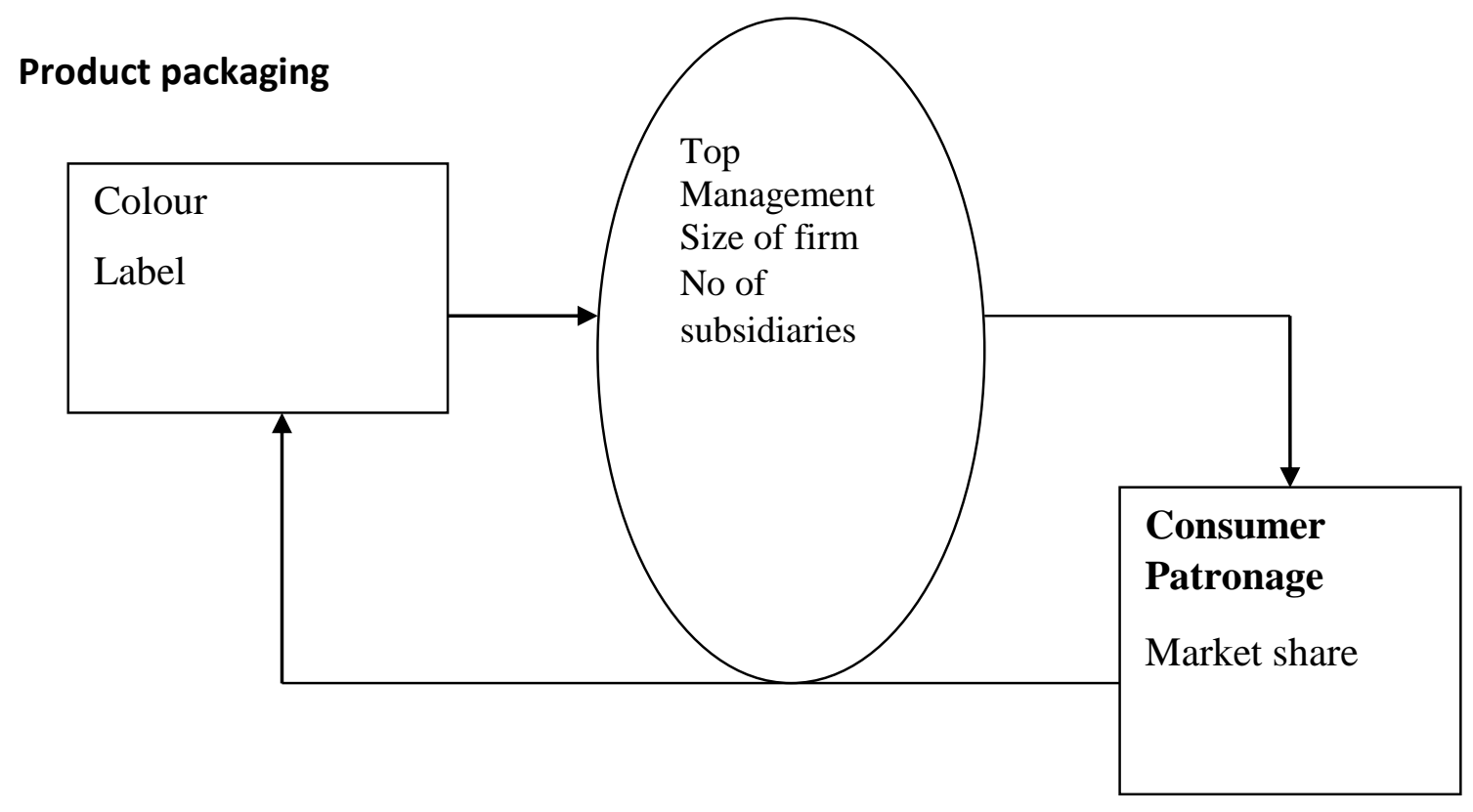

\section{Methodology}

Fig 2.1 : Researcher Computation

This chapter addresses the methodology adopted for the analysis of the impact of product packaging and consumer patronage in Cadbury, Nigeria. It is organized as follows: Research Design, Sources of data, Sample size and Sampling Technique, Research Instruments, administration of the research instrument, model specification, measurement of variables, and data analysis techniques.

A cross-sectional survey research design will be used in carrying out this study. A crosssectional survey offers the opportunity to collect data across different sectors per time period. In this study, we are interested in Cadbury Plc and test this relationship. With respect to the time period over which data will be collected, which will be one point in time in the company in the industry, a cross-sectional survey is found appropriate. Further, it is ideal because the researcher intends to collect descriptive data that is accorded statistical treatment to allow for hypothesis testing to come up with objective conclusions (Cooper and Schindler, 2003).

The population of the study comprises of 250 management staff in Cadbury plc Lagos state which is are capable of giving us the information needed for this study from (Wiki Loves Africa:) The sample size of this study was derived using Taro Yamane formula $\mathrm{S}=\frac{N}{1+N\left(x^{2}\right)}$

The variable Nrepresents the population of the study which is 250, Margin of error is donated

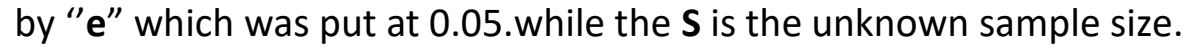




$$
\begin{gathered}
\frac{250}{1+250\left(0.05^{2}\right)} \\
\frac{250}{1+250(0.0025)} \\
\frac{250}{1+0.625} \\
\frac{250}{1.625} \\
154 \text { staff }
\end{gathered}
$$

For this research, simple random technique was used on the population. The respondents were chosen at random. Two hundred and fifty individuals were randomly. The respondents consisted of both male and female

Primary data are first hand data obtained from the respondents. This study will use primary sources of data collection. Primary data will be obtained through administration of questionnaire to the respondents. Secondary data are data obtained from review of related literatures of opinions of expects in the subject matter. For this study data were obtained from text books, magazine, newspaper, journals, public and academic libraries, company's annual publications,

The main instrument of this study will be structured questionnaire designed to collect information from the respondents. The questionnaire consists of closed ended questions specifically designed to achieve the objective of the study and to analyze the research hypothesis. Structured questionnaire administered to each respondents were used to obtain qualitative information about the study.

To provide answers to research questions and the objective, information gathered on all relevant variables were analyzed using descriptive(frequencies, percentage, mean, and standard deviation) and inferential (regression) statistics with the use of SPSS statistical packages version 20 In a general term, let product packaging and consumer patronage of a firm be denoted by:

$\mathrm{CP}=\mathrm{f}(\mathrm{PP})$ 3.1.

$\mathrm{CP}=\mathrm{F}$ (Colour and Label)

$P F=\alpha_{0}+\beta_{1} C+\beta_{2} L+\varepsilon$ .eqn 3.3

Where:.

$\alpha=$ Constant

\section{Data Presentation and Analysis of Result}

This chapter presents the results obtained from the study in the form of tables to which inference were made. The study considered the analysis of data generated from the research study in relation to the responses obtained through the administration of questionnaire. A total of 154 questionnaires were distributed for the study. Out of which 150 were retrieved from the respondents. The data presented, analyzed and interpreted were based on the retrieved questionnaires. 
INTERNATIONAL JOURNAL OF ACADEMIC RESEARCH IN BUSINESS AND SOCIAL SCIENCES Vol. 9, No. 7, July, 2019, E-ISSN: 2222-6990 @ 2019 HRMARS

Table 4.1 : Demographic Characteristics of the Respondents

\begin{tabular}{|c|c|c|c|c|c|}
\hline \multicolumn{6}{|c|}{ DEMOGRAPHIC CHARACTERISTICS } \\
\hline & & FREQUENCY & PERCENT & $\begin{array}{l}\text { VALID } \\
\text { PERCENT }\end{array}$ & $\begin{array}{l}\text { CUMULATIVE } \\
\text { PERCENT }\end{array}$ \\
\hline \multirow{3}{*}{ GENDER } & MALE & 86 & 61.7 & 61.7 & 61.7 \\
\hline & FEMALE & 64 & 38.3 & 38.3 & 100.0 \\
\hline & TOTAL & 150 & 100.0 & 100.0 & \\
\hline \multirow{5}{*}{ AGE GROUP } & $21-30$ & 20 & 25.5 & 25.5 & 25.5 \\
\hline & $31-40$ & 101 & 40.3 & 40.3 & 65.8 \\
\hline & $41-50$ & 22 & 26.6 & 26.6 & 92.4 \\
\hline & 51 and Above & 7 & 7.6 & 7.6 & 100.0 \\
\hline & TOTAL & 150 & 100.0 & 100.0 & \\
\hline \multirow{5}{*}{$\begin{array}{l}\text { MARITAL } \\
\text { STATUS }\end{array}$} & Single & 33 & 29.5 & 29.5 & 29.5 \\
\hline & Married & 87 & 60.8 & 60.8 & 90.3 \\
\hline & Divorced & 11 & 4.0 & 4.0 & 94.2 \\
\hline & Widowed & 19 & 5.8 & 5.8 & 100.0 \\
\hline & TOTAL & 150 & 100.0 & 100.0 & \\
\hline \multirow{4}{*}{ RELIGION } & Christianity & 83 & 71.2 & 71.2 & 71.2 \\
\hline & Islam & 47 & 21.6 & 21.6 & 92.8 \\
\hline & Other & 20 & 7.2 & 7.2 & 100.0 \\
\hline & TOTAL & 150 & 100.0 & 100.0 & \\
\hline \multirow{6}{*}{$\begin{array}{l}\text { EDUCATIONAL } \\
\text { BACKGROUND }\end{array}$} & WAEC/SSCE/GCE & 10 & 4.7 & 3.7 & 3.7 \\
\hline & OND & 40 & 37.6 & 37.6 & 41.3 \\
\hline & B.Sc./HND & 69 & 45.3 & 45.3 & 86.6 \\
\hline & MBA/M.Sc. & 18 & 6.7 & 7.7 & 94.3 \\
\hline & Phd & 13 & 5.7 & 5.7 & 100.0 \\
\hline & TOTAL & 150 & 100.0 & 100.0 & \\
\hline
\end{tabular}

Source: Field Survey 2019

The analysis in Table 4.1 represents the socio-demographic characteristics of the respondents of this study. The analysis shows gender participation in which $86(61.7 \%)$ of the respondents were males while 64(38.3\%) were females. The result shows that majority of respondents were males.

In terms of age, majority of the respondents representing $101(40.3 \%)$ were within the age bracket 31-40years, 22(26.6\%) were within the age bracket of $41-50$ years, $20(25.5 \%)$ of the respondents were within the age group $21-30$ years while $7(7.6 \%)$ of the respondents were over 51 years.

In terms of marital status, the table shows that $87(60.8 \%)$ were married, $33(29.5 \%)$ were single. $19(5.8 \%)$ were widowed while $4.0 \%(11)$ of the respondents were divorced.

In terms of religious belief, $83(71.2 \%)$ of the respondents were of Christian belief, $47(21.6 \%)$ of the respondents were Muslims, while 20(7.2) were believers of other religions not specifically indicated. 
INTERNATIONAL JOURNAL OF ACADEMIC RESEARCH IN BUSINESS AND SOCIAL SCIENCES Vol. 9, No. 7, July, 2019, E-ISSN: 2222-6990 @ 2019 HRMARS

On the qualifications of the respondents, Table 4.1 shows that majority 69 (45.3\%) of the respondents possessed BSC/HND certificates and this was closely followed by the holders of OND 40(37.6\%). Also, the holders of MSc/MBA were $18(6.7 \%)$, while $13(5.7 \%)$ of the respondents were holders of PhD, Also, the holders of WAEC/SSCE/GCE were 10(4.7\%) of the respondents indicating that our respondents were educated enough to know and understand the questionnaire given to them.

\section{Analysis of the Research Objectives}

Table 4.2 product Packaging ics and Physical characteristics

\begin{tabular}{|c|l|l|l|l|}
\hline & & & & $\begin{array}{l}\text { Cumulative } \\
\text { Percent }\end{array}$ \\
\hline A & 105 & 70.0 & 70.0 & 70.0 \\
SA & 45 & 30.0 & 30.0 & 100.0 \\
Tota & 150 & 100.0 & 100.0 & \\
I & & & Percent & Valid Percent \\
\hline
\end{tabular}

\section{Source: Field Survey 2019}

From Table 4.2 above $45(30 \%)$ of the respondents strongly agreed that packaging decisions are influenced by certain physical characteristics of the product,105(70\%) of the respondents agreed. It is apparent that majority of the respondents are aware that packaging decisions are influence by certain physical characteristics of the product.

Table 4.3 Product Chemical Factors and their Importance

\begin{tabular}{|c|c|c|c|c|c|}
\hline & & Frequency & Percent & Valid Percent & $\begin{array}{l}\text { Cumulative } \\
\text { Percent }\end{array}$ \\
\hline \multirow[t]{7}{*}{ Valid } & SD & 16 & 10.6 & 10.6 & 10.6 \\
\hline & D & & & & \\
\hline & $\mathrm{N}$ & 12 & 8.0 & 8.0 & 18.6 \\
\hline & & 25 & 16.7 & 16.1 & 35.3 \\
\hline & A & 88 & 58.8 & 58.8 & 94.1 \\
\hline & SA & 9 & 5.9 & 5.9 & 100.0 \\
\hline & Total & 150 & 100.0 & 100.0 & \\
\hline
\end{tabular}

Source: Field Survey 2019

From Table 4.3 above 9(5.9\%) of the respondents strongly Agreed that certain physio-chemical factors are important factors to considered while making packaging decisions, $88(58.8 \%)$ of the respondents agreed, $25(16.7 \%)$ of the respondents were undecided while $12(8.0 \%)$ and $16(10.8 \%)$ of the respondent disagreed and strongly disagreed. This implies that majority of the respondents agreed that physio-chemical factors are important factors to considered. 
INTERNATIONAL JOURNAL OF ACADEMIC RESEARCH IN BUSINESS AND SOCIAL SCIENCES Vol. 9, No. 7, July, 2019, E-ISSN: 2222-6990 ¿ 2019 HRMARS

Table 4.4 Packaging Should Also Necessarily Possess the Quality Of Connievence

\begin{tabular}{|c|c|c|c|c|c|}
\hline & & Frequency & Percent & Valid Percent & $\begin{array}{l}\text { Cumulative } \\
\text { Percent }\end{array}$ \\
\hline \multirow{5}{*}{ Valid } & $D$ & 9 & 5.9 & 5.9 & 5.9 \\
\hline & $\mathrm{N}$ & 33 & 22.0 & 22.0 & 22.0 \\
\hline & $A$ & 87 & 58.1 & 58.1 & 58.1 \\
\hline & SA & 21 & 14.0 & 14.0 & 100.0 \\
\hline & Total & 150 & 100.0 & 100.0 & \\
\hline
\end{tabular}

Source: Field Survey 2019

From Table 4.4 above 21(14.0\%) of the respondents Strongly Agreed that packaging should also necessarily possess the quality of connievence, $87(58.1 \%)$ Of the respondents Agreed, 33(22\%) of the respondents were Undecided, while $9(5.9 \%)$ of the respondents Disagreed. The implication of this table is that majority of the respondents were in agreement that packaging possess the quality of conveniences.

Table 4.5 cost of product packaging and features

\begin{tabular}{|c|c|c|c|c|c|}
\hline & & Frequency & Percent & Valid Percent & $\begin{array}{l}\text { Cumulative } \\
\text { Percent }\end{array}$ \\
\hline \multirow[t]{6}{*}{ Valid } & SD & 2 & 1.3 & 1.3 & 1.3 \\
\hline & $\mathrm{D}$ & 2 & 1.3 & 1.3 & 2.6 \\
\hline & $\mathrm{N}$ & 23 & 15.4 & 15.4 & 18 \\
\hline & $A$ & 90 & 60.0 & 60.0 & 78 \\
\hline & SA & 33 & 22.0 & 22.0 & 100.0 \\
\hline & $\begin{array}{l}\text { Tot } \\
\text { al }\end{array}$ & 150 & & & \\
\hline
\end{tabular}

\section{Source: Field Survey 2019}

From Table 4.5 above, 33(22.0\%) of the respondents strongly Agreed that the cost of packaging a product matters in deciding which packaging features to use, 90(60.0\%) of the respondents Agreed, $23(15.4 \%)$ of the respondents were Neutral, also 2(1.3\%) of the respondents Disagreed while 2(1.3\%) of the respondents strongly Disagreed. The table revealed that cost of packaging is a factor to consider when making decision about packaging.

Table 4.6 Purchases Decision and Effective Packaging

\begin{tabular}{|ll|l|l|l|l|}
\hline & Frequency & Percent & Valid Percent & Cumulative Percent \\
\hline Valid & D & 15 & 10.0 & 10.0 & 10.0 \\
& N & 30 & 20.0 & 20.0 & 30.0 \\
& A & 30 & 20.0 & 20.0 & 50.0 \\
SA & 75 & 50.0 & 50.0 & 100.0 \\
Total & 150 & 100.0 & 100.0 & \\
\hline
\end{tabular}


INTERNATIONAL JOURNAL OF ACADEMIC RESEARCH IN BUSINESS AND SOCIAL SCIENCES Vol. 9, No. 7, July, 2019, E-ISSN: 2222-6990 @ 2019 HRMARS

\section{Source: Field Survey 2019}

From Table 4.6 above, 75(50.0\%) of the respondents strongly Agreed that More purchases decision are made through the of effective packaging, 30(20.0\%) of the respondents Agreed, 30(20.0\%) of the respondents were Neutral, while $15(10 \%)$ of the respondents strongly Disagreed. The table revealed that More purchases decision are made through the of effective packaging.

Table 4.7 Packaging and Purchasing Decision

\begin{tabular}{|ll|l|l|l|l|}
\hline & Frequency & Percent & Valid Percent & Cumulative Percent \\
\hline Valid & SD & 15 & 10.0 & 10.0 & 10.0 \\
& D & 30 & 20.0 & 20.0 & 30.0 \\
& A & 90 & 60.0 & 60.0 & 90.0 \\
SA & 15 & 10.0 & 10.0 & 100.0 \\
Total & 150 & 100.0 & 100.0 & \\
\hline
\end{tabular}

Source: Field Survey 2019

From Table 4.7 above, 15(10.0\%) of the respondents strongly Agreed that packaging has a positive relationship with purchasing decision, 90(20.0\%) of the respondents Agreed, $30(20.0 \%)$ of the respondents were Neutral, while $15(10 \%)$ of the respondents strongly Disagreed. The table revealed that packaging has a positive relationship with purchasing decision.

Table 4.8 Product Attractiveness and Customers Buying Decision

\begin{tabular}{|ll|l|l|l|l|}
\hline & & & & Cumulative \\
& & Frequency & Percent & Valid Percent & Percent \\
\hline Valid & D & 15 & 10.0 & 10.0 & 10.0 \\
& A & 75 & 50.0 & 50.0 & 60.0 \\
& SA & 60 & 40.0 & 40.0 & 100.0 \\
& Total & 150 & 100.0 & 100.0 & \\
\hline
\end{tabular}

Source: Field Survey 2019

From Table 4.8 above, 60(40.0\%) of the respondents strongly Agreed that Most customers are buying only because of the attractiveness of a product, 75(50.0\%) of the respondents Agreed, while 15(10\%) of the respondents were Neutral. The table revealed that Most customers are buying only because of the attractiveness of a product.

Table 4.9 Frequently Product Purchases Consumers Buying Decison

\begin{tabular}{|ll|l|l|l|l|}
\hline & Frequency & Percent & Valid Percent & Cumulative Percent \\
\hline Valid & A & 90 & 60.0 & 60.0 & 60.0 \\
& SA & 60 & 40.0 & 40.0 & 100.0 \\
& Total & 150 & 100.0 & 100.0 & \\
\hline
\end{tabular}

\section{Source: Field Survey 2019}

From Table 4.9 above, 60(40.0\%) of the respondents strongly Agreed that Frequently purchases are made when packaging of a product that is useful to consumers, while $90(60.0 \%)$ of the respondents 
INTERNATIONAL JOURNAL OF ACADEMIC RESEARCH IN BUSINESS AND SOCIAL SCIENCES Vol. 9, No. 7, July, 2019, E-ISSN: 2222-6990 @ 2019 HRMARS

Agreed. This revealed that Frequently purchases are made when packaging of a product that is useful to consumers

Table 4.10 Relationship Between Packaging and Sales Volume

\begin{tabular}{|ll|l|l|l|l|}
\hline & Frequency & Percent & Valid Percent & Cumulative Percent \\
\hline Valid & D & 15 & 10.0 & 10.0 & 10.0 \\
& N & 15 & 10.0 & 10.0 & 20.0 \\
A & 90 & 60.0 & 60.0 & 80.0 \\
SA & 30 & 20.0 & 20.0 & 100.0 \\
Total & 150 & 100.0 & 100.0 & \\
\hline
\end{tabular}

\section{Source: Field Survey 2019}

From Table 4.10 above, 30(20.0\%) of the respondents strongly Agreed that packaging has a positive influence on sale volume, $90(60.0 \%)$ of the respondents Agreed, 15(10.0\%) of the respondents were Neutral, while $15(10 \%)$ of the respondents Disagreed. The implication is that majority of the respondents agreed that packaging has a positive influence on sale volume.

Table 4.11 Product packaging and Buying Decision

\begin{tabular}{|ll|l|l|l|l|}
\hline & Frequency & Percent & Valid Percent & Cumulative Percent \\
\hline Valid & SD & 15 & 10.0 & 10.0 & 10.0 \\
& D & 15 & 10.0 & 10.0 & 20.0 \\
N & 30 & 20.0 & 20.0 & 40.0 \\
A & 75 & 50.0 & 50.0 & 90.0 \\
SA & 15 & 10.0 & 10.0 & 100.0 \\
Total & 150 & 100.0 & 100.0 & \\
\hline
\end{tabular}

\section{Source: Field Survey 2019}

From Table 4.11 above, 15(10.0\%) of the respondents strongly Agreed that product packaging encourages buyer to buy, $75(50.0 \%)$ of the respondents Agreed, 30(20.0\%) of the respondents were Neutral, while $15(10 \%)$ of the respondents Disagreed, while $15(10 \%)$ of the respondents Strongly Disagreed. The implication is that majority of the respondents agreed that product packaging encourages buyer to buy.

Table 4.12 packaging and Customers' Attention

\begin{tabular}{|ll|l|l|l|l|}
\hline & Frequency & Percent & Valid Percent & Cumulative Percent \\
\hline Valid & SD & 30 & 20.0 & 20.0 & 20.0 \\
& D & 15 & 10.0 & 10.0 & 30.0 \\
N & 15 & 10.0 & 10.0 & 40.0 \\
A & 75 & 50.0 & 50.0 & 90.0 \\
SA & 15 & 10.0 & 10.0 & 100.0 \\
Total & 150 & 100.0 & 100.0 & \\
\hline
\end{tabular}

Source: Field Survey 2019 
From Table 4.12 above, 15(10.0\%) of the respondents strongly Agreed that packaging is the best to call the attention of customers, 75(50.0\%) of the respondents Agreed, 15(10.0\%) of the respondents were Neutral, while $15(10 \%)$ of the respondents Disagreed, while $30(20 \%)$ of the respondents Strongly Disagreed. The implication is that most of the respondents agreed that packaging is the best to call the attention of customers.

Table 4.13 Product packaging and Organization Performance

\begin{tabular}{|ll|l|l|l|l|}
\hline & Frequency & Percent & Valid Percent & Cumulative Percent \\
\hline Valid & SD & 30 & 20.0 & 20.0 & 20.0 \\
& A & 45 & 30.0 & 30.0 & 50.0 \\
& SA & 75 & 50.0 & 50.0 & 100.0 \\
& Total & 150 & 100.0 & 100.0 & \\
\hline
\end{tabular}

Source: Field Survey 2019

From Table 4.13 above, 75(10.0\%) of the respondents strongly Agreed that packaging is the key to success in any organisation, $45(30.0 \%)$ of the respondents Agreed, while $30(20.0 \%)$ of the respondents Strongly Disagreed. The implication is that majority of the respondents agreed that packaging is the key to success in an organization.

\section{Test of Hypotheses}

Inferential (regression) statistics tools used to drive the value of a dependents variable from several other independent variable or predictor variable. It is used to assess the how and to what extents they affect or influence a certain outcome.

\section{Hypothesis One}

$\mathbf{H}_{0}$ : There is no significant relationship between product packaging and Buying behavior of Cadbury $\mathbf{H}_{1}$ : There is significant relationship between product packaging and buying behavior of Cadbury 
INTERNATIONAL JOURNAL OF ACADEMIC RESEARCH IN BUSINESS AND SOCIAL SCIENCES

Vol. 9, No. 7, July, 2019, E-ISSN: 2222-6990 @ 2019 HRMARS

Table 4.14 The Effect of Product Packaging on the Buying Behavior

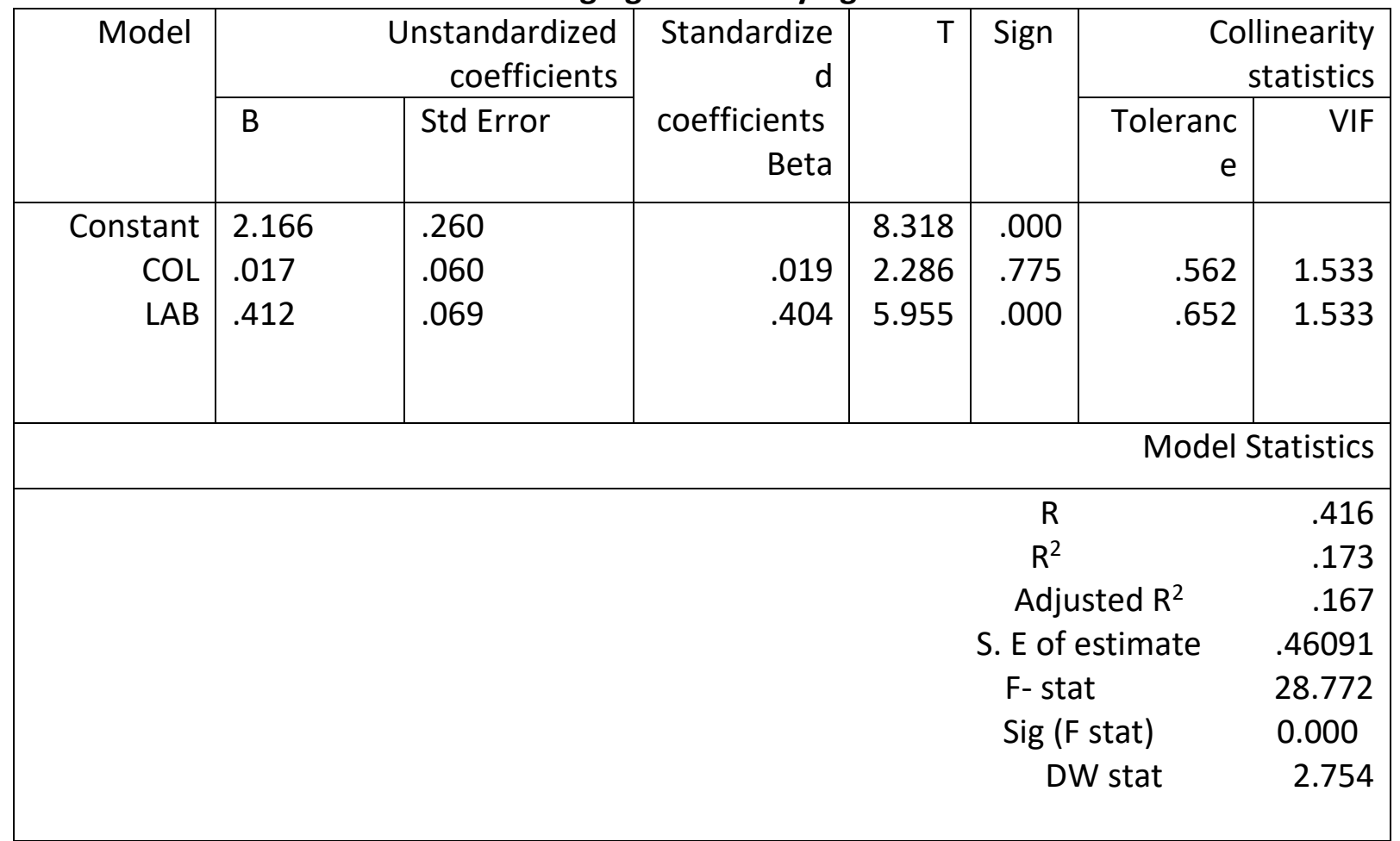

Source: Field Survey, 2019.

a.Dependent variable MK

Predictors: (Constant), COL,LAB.

$\mathrm{COL}=$ Colour

$\mathrm{LAB}=$ Label

$\mathrm{CD}=$ Consumer Decision

The analysis in Table 4.14 indicates the effect of Packaging on buying decison. The results revealed that the predictor variables (Colour and Label) were individually statistically significant to consumer decision of Cadbury product. Colour explained $17 \%$ of the variance in the consumer decision while Label explained $41.2 \%$ of the variance in the consumer decision of cadbury. However, the overall effect of packaging on consumer decision was significant $(F=28.772, p<0.00)$.

In addition, multiple regressions simply measures the naturally occurring scores on a number of predictor variables and try to establish which set of the observed variables gives rise to the best prediction of the dependent variables. The $\mathrm{R}$ value was .416 which represented the simple correlation and therefore indicated a good degree of correlation. Adjusting to a degree of freedom, our model could still account for $16.7 \%$ of the variation in the consumer decision while $67.6 \%$ in their performance variation were accounted for by other variable not included in this study. The regression assumptions were also checked by autocorrelation and multi-collinearity tests. The results of the Durbin Watson (DW) was satisfactory at 2.754 implying that in this model the residuals are not auto-correlated as the value is greater than 2 . The multi-collinearity of the variables in the model was verified by the Tolerance (Tol.) and the values were satisfactory. The Tolerance values were high ranging from 0.562 to 0.652 which are far above 0.1 the worrying level and the Variance Inflation 
INTERNATIONAL JOURNAL OF ACADEMIC RESEARCH IN BUSINESS AND SOCIAL SCIENCES

Vol. 9, No. 7, July, 2019, E-ISSN: 2222-6990 @ 2019 HRMARS

Factor (VIF) values ranging from 1.533 and 1.533 were also lower than the worrying level of 10 and above indicating that there were no multi-collinearity problems among the independent variables in the data.

\section{Hypothesis Two}

$\mathbf{H}_{\mathbf{0}}$ : There is no significant relationship between product packaging and market share of Cadbury $\mathbf{H}_{1}$ : There is no significant relationship between product packaging and market share of Cadbury

Table 4.15 Influence of Product Packaging and Market Share

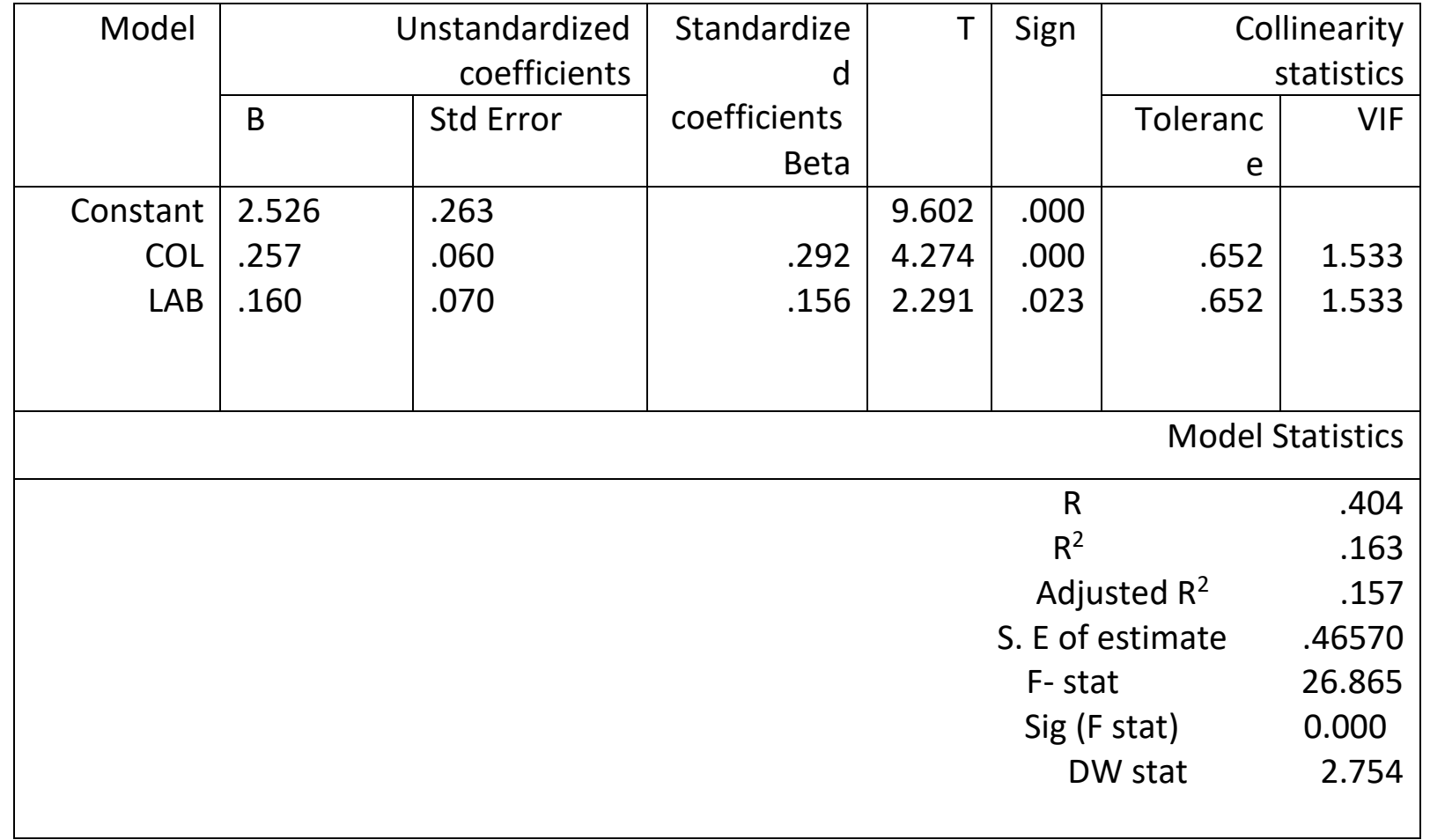

Source: Field Survey, 2018.

a.Dependent variable MKS

Predictors: (Constant), COL,LAB.

$\mathrm{COL}=$ Colour

$\mathrm{LAB}=$ Label

$\mathrm{P}=$ market share

The analysis in Table 4.15 indicates the influence of packaging on market share. The results revealed that the predictor variables (colour and label) were individually statistically significant to market share. colur explained $25.7 \%$ of the variance in the market share while label explained $16.0 \%$ of the variance in the market share. However, the overall effect of product packaging was significant $(F=26.865, p<0.00)$.

In addition, multiple regressions simply measures the naturally occurring scores on a number of predictor variables and try to establish which set of the observed variables gives rise to the best prediction of the dependent variables. The $\mathrm{R}$ value was .404 which represented the simple correlation 
and therefore indicated a good degree of correlation. Adjusting to a degree of freedom, our model could still account for $15.7 \%$ of the variation in the performance while $67.6 \%$ in their performance variation were accounted for by other variable not included in this study. The regression assumptions were also checked by autocorrelation and multi-collinearity tests. The results of the Durbin Watson (DW) was satisfactory at 2.754 implying that in this model the residuals are not autocorrelated as the value is greater than 2 . The multi-collinearity of the variables in the model was verified by the Tolerance (Tol.) and the values were satisfactory. The Tolerance values were high ranging from 0.652 to 0.652 which are far above 0.1 the worrying level and the Variance Inflation Factor (VIF) values ranging from 1.533 and 1.533 were also lower than the worrying level of 10 and above indicating that there were no multi-collinearity problems among the independent variables in the data.

\section{Summary, Conclusion and Recommendations}

This chapter discusses summary of findings, the conclusion and Recommendation as well as Direction for further Research's. This Research work has examined the role of product packaging and its influence on consumer patronage of Cadbury Plc.

\section{Summary of Findings}

This Research study reviewed the role of product packaging and its influence on consumer's patronage of Cadbury Plc. Findings of the result reviewed that product packaging has s significant effect on consumer patronage. This is shown in response to Table 4.11 as $50 \%$ of the respondents in the survey agreed that consumer buying behavior is been influence by product packaging. This is also shown in response to Table 4.13 as $50 \%$ of the respondents in the survey Strongly agreed that product packaging influence the performance of an organization. This study further showed that product packaging has the ability to increase the sale of an organization as showed in response in Table 4.10 as $60 \%$ of the respondents agreed that packaging has a positive relationship with sale volume of an organization. From the findings, in the Hypothesis 1, F stats of 28.772 was obtained. This was significant as the $p$ value is less than 0.05 . Thus, we reject the Null hypothesis that there is no significant relationship between product packaging and consumer patronage and accept the alternative hypothesis which state that there is significant relationship between product packaging and consumer patronage. From the findings, Hypothesis 2, F stats of 26.865 was obtained. This was significant as the $p$ value is less than 0.05 . Thus, we reject the Null hypothesis that there is no significant relationship between product packaging and purchasing decision and accept the alternative hypothesis which state that there is significant relationship between product packaging and purchasing Decision.

\section{Conclusion}

Product packaging has been found to have favorable effect on consumer patronage and consumer purchasing decision as well as increasing the market share of Cadbury Plc. Thus, Colour and Label should be seen as inevitable tools to increase market shares in an Cadbury Plc. 
INTERNATIONAL JOURNAL OF ACADEMIC RESEARCH IN BUSINESS AND SOCIAL SCIENCES Vol. 9, No. 7, July, 2019, E-ISSN: 2222-6990 @ 2019 HRMARS

\section{Recommendation}

In other to fully benefit from the importance of product packaging, this recommendation was made. Cadbury Plc should focus much of their attention on Colour and Labelling of their products so that their market share can be increase, because colour and label call the attention of market people.

The significance of the study is that it add to the body of knowledge by making it open to Cadbury plc and other organization that colour and label are both significant element of product packaging that will enhance market share.

Finally, the researchable aspect of the concept of products packaging as not been exhausted in this study. Therefore, suggestion are been put forward for further research into the concept of product packaging especially in the area of problem that limit the adoption of product packaging.

\section{References}

Adeola, O. (2017) Effect of product packaging on Nigerian consumers' behaviour, the school of business and entrepreneurship American university of Nigeria Yola, Adamawa state, Nigeria.

Ahmed, U., Majid, A. H., Zin, M. L., Phulpoto, W., \& Umrani, W. A. (2016). Role and impact of reward and accountability on training transfer. Business and Economics Journal, 7(1). http://dx.doi.org/10.4172/2151-6219.1000195

Bagozzi, R. \&Warsaw, L. (1990) "Trying to Consumer" Journal of Consumer Research 17, (2) pp.127 140

Baker, J. (1987). The role of the environment in marketing services: The consumer perspective. In J. A. Czepiel, C. A. Congram, \& J. Shanahan (Eds.), The services challenge: Integrating for competitive advantage (pp. 79-84). Chicago: American Marketing Association

Best, R. J. (2002). Marketing Based Management: Strategic for Growing Customer value and Profitability, Prentice hall, New York

Bucker, C. (2001) Business Week Magazine April 2001 Editorial

Cateora, P. and Graham, J. (2002), International Marketing, New York: McGraw-Hill, pg 358-360.

Chukwu., B. A., Enudu T. O., (2018) The Impact Of Product Packaging On Consumers' Purchasing Behavior In Benin Metropolis, Edo State, Nigeria, International Journal of Economics, Commerce and Management United Kingdom Vol. VI, Issue 4, April Licensed under Creative Common Page 708 http://ijecm.co.uk/ISSN 23480386

Coulson, N. S., (2000), "An application of the stages of change model to consumer use of food labels", British Food Journal, 102, 9, 661-8.

Deliya, M. M. and Parmar, J. B. (2012). Role of packaging on consumer buying behavior-patan district. Global Journal of Management and Business Research, 12(10): 49-67

Galdeano, D., Ahmed, U., Fati, M., Rehan, R., \& Ahmed, A. (2019). Financial performance and corporate social responsibility in the banking sector of Bahrain: Can engagement moderate?. Management Science Letters, 9(10), 1529-1542.

Kamaladevi, B. (2010). "Customer Experience Management in Retailing” Business Intelligence Journal, 3 (1), 37- 54.

Keller, K. L., (2009). Choosing Brand Elements to build Brand Equity. Strategic Brand Management. 3rd ed. Delhi: Dorling Kindersley. Pp.187-96

Kotler, P., (2000). Marketing management. Upper Saddle River, New Jersey: Prentice-Hall. 
INTERNATIONAL JOURNAL OF ACADEMIC RESEARCH IN BUSINESS AND SOCIAL SCIENCES

Vol. 9, No. 7, July, 2019, E-ISSN: 2222-6990 @ 2019 HRMARS

Ladipo, P. K. and Rahim, A. G. (2013). “Packaging and the Influence of Information Overload in a Lowrisk Market: A Study of Grocery Products" European Journal of Business and Social Sciences, 1 (10), 61- 72.

Lee, S. G. and Lye, S. W. (2002). Design for manual packaging. International Journal of Physical Distribution and Logistics Management, 33(2): 163-189.

Lifu, F. L. (2003) Product Packaging and its effect on Consumer Buying Choice in Calabar. Unpulished M.Sc. Thesis, University of Calabar, Nigeria. Lifu, F.L (2012) An Analysis of the effect of product packing on consumers' Buying Choice in Calabar Municipality, Cross River State Nigeria. Aisan Journal of Business Management 4, 186 - 191

Nayyar, E. V. (2012). "Packaging - An Innovative Source of Impulsive and Abrupt Buying Action" International Journal of Management and Information Technology, 1 (1), 13- 16

Oladele, P. O. (2012). Moderating Consumer Relationship Management (CRM) to Enhance Firm's Performance through Continuous Product Development" Australian Journal of Business and Management Research (AJBMR), 2 (1), 1-8.

Oliver, K. (1997) Supremacy of Company Brand-The Central Basis of Market Share. Academic press, san Diego Palmer,A (1998)Principles of Service Marketing 2nd ,Mc Graw Hill companies, Inc

Rundh, B. (2005). The multi-faceted dimension of packaging. British Food Journal, 107 (9), 670-684.

Scott, Y. (2008) Packaging and the Environment. A Cross-cultural perspective. Design Management Review 19, $42-48$

Silayoi, P. \& Speece, M. (2004) Packaging and Purchase Decisions. An Explanatory study on the Impact of involvement level and time pressure. British Food Journal 106, 607-628

Smith, P., \& Taylor, J. (2004). Marketing communications: an integrated approach. 4th ed. London: Kogan Page.

Underwood, R. L., (2003). The communicative power of product packaging: creating brand identity via lived and mediated experience. Journal of Marketing Theory and Practice, winter, 62-76

Utrich, R. O. D., Campana, \& Malkewitz, K. (2010) Formation of consumer price expectation based on package design. Attractive and Quality routes. Journal of Marketing Theory and Practice 1, 23 $-40$

Alervall, V., Saied, J. S. (2013). "Perspectives on elements of packaging design." (2013): 26. White, Sheen. "Influence of packaging on consumer buying behaviour." (n.d.): 7.

Wells, L. E., Farley, H., \& Armstrong, G. A. (2007). The importance of packaging design for own-label food brands. International Journal of Retail \& Distribution Management, 35 (9), 677-690.

Williams, T. G. (1982). Consumer Behaviour: Fundamentals and Strategies. New York: West Publishing Company 